5. Perez K, Castillo J, Dezube BJet al.Human immunodeficiency virus-associated anaplastic large cell lymphoma. Leuk Lymphoma 2010; 51: 430.

6. Balachandran I, Walker JW Jr, Broman J. Fine needle aspiration cytology of ALK1(-), CD30+ anaplastic large cell lymphoma post renal transplantation: a case report and literature review. Diagn Cytopathol 2010; 38:213.
7. Gopal AK, Ramchandren R, O’Connor OA et al. Safety and efficacy of brentuximab vedotin for Hodgkin lymphoma recurring after allogeneic stem cell transplantation. Blood 2012; 120: 560.

8. Younes A, Bartlett NL, Leonard JP, et al Brentuximab vedotin (SGN-35) for relapsed CD30-positive lymphomas. N Engl J Med 2010; 363: 1812 .
9. Galand C, Donnou S, Crozet L, et al. Th17 cells are involved in the local control of tumor progression in primary intraocular lymphoma. PLoS One 2011; 6: e24622.

10. Kesselring R, Thiel A, Pries R, et al. The number of CD161 positive Th17 cells are decreased in head and neck cancer patients. Cell Immunol 2011; 269: 74.

\title{
Early and Late Posttransplant Lymphoproliferative Disorder After Lung Transplantation-34 Cases From the European PTLD Network
}

$\mathrm{J}^{\mathrm{a}}$ aksch et al. (1) have recently reported a low incidence of posttransplant lymphoproliferative disorder (PTLD) of Bcell origin after lung transplantation (18 in a series of 1157 [1.6\%] consecutive patients) in Vienna. Their findings show that posttransplantation management is crucial to PTLD prevention and document the effectiveness of the program in Vienna. The authors hypothesize that their use of anti-cytomegalovirus (CMV) immunoglobulin prophylaxis (Cytotect, $1 \mathrm{~mL} / \mathrm{kg}$ intravenously on days $1,7,14$, and 21 postoperatively) protects patients from Epstein-Barr virus (EBV)-associated PTLD. This hypothesis is based on the findings by Opelz et al. (2) who had observed no cases of PTLD within the first year after transplantation in 2103 kidney transplant recipients who had received anti-CMV immunoglobulin prophylaxis for 4 months after transplantationsignificantly less than in an untreated control group. However, in the subsequent 5 years, new cases of PTLD developed at similar rates in the examined groups with and without $\mathrm{CMV}$ prophylaxis.

We were intrigued by the low proportion of late PTLD reported (only 3 of 18 cases occurred $>1$ year after transplantation) and analyzed time-to-PTLD in lung transplant recipients in the PTLD-1 (3) and PTLD 1-3 (4) trials as well as those treated at Hopital Pitie-Salpêtriere, Paris, or reported to the German PTLD registry. Overall, 34 patients with PTLD after lung transplantation were included from centers in Australia, Austria, Belgium, France, and Germany. Twenty-two of 34 had received lung transplants and 12 of 34 had received combined heart/lung transplants between 1988 and 2011. Strikingly, in both groups, less than $40 \%$ of cases occurred in the first year after transplantation (early PTLD) (Table 1). We observed cases later than 2 years (16 of $34[47 \%]), 5$ years (10 of 34 [29\%]), and 10 years (6 of 34 [18\%]). Furthermore, 6 of 31 patients with PTLD after lung or heart/lung transplantation evaluated for EBV association had EBV-negative disease by EBV-encoded RNA in situ hybridization. These included two cases of diffuse large B-cell lymphoma (DLBCL)-PTLD

TABLE 1. Time to PTLD in lung transplant recipients reported to the European PTLD network

Transplant year

Time to PTLD

\begin{tabular}{|c|c|c|c|c|c|c|c|c|}
\hline \multirow[b]{2}{*}{$\begin{array}{l}\text { Transplanted } \\
\text { organ }\end{array}$} & \multirow[b]{2}{*}{$\mathbf{n}$} & \multirow[b]{2}{*}{$\begin{array}{l}\text { Male, } \\
\text { n (\%) }\end{array}$} & & & \multirow[b]{2}{*}{$\begin{array}{c}\text { Histology } \\
\text { (PTLD subtype) }\end{array}$} & \multirow[b]{2}{*}{$\begin{array}{c}\text { EBV } \\
\text { association }^{a}\end{array}$} \\
\hline & & & $\begin{array}{l}\text { Median } \\
\text { (range) }\end{array}$ & $\begin{array}{c}\text { Median } \\
\text { (years) }\end{array}$ & $\begin{array}{l}\text { Range } \\
\text { (years) }\end{array}$ & Early & & \\
\hline $\begin{array}{l}\text { Lung and } \\
\text { heart/lung }\end{array}$ & 34 & $16(47 \%)$ & $2001(1988-2011)$ & 1.83 & $0.14-23.43$ & $12 / 34(35 \%)$ & $\begin{array}{c}22 \text { DLBCL PTLD } \\
1 \text { PBL PTLD } \\
2 \text { MZL PTLD } \\
2 \text { Plasmacytoma-like PTLD } \\
2 \text { Polymorphic PTLD } \\
2 \text { Lymphoplasmocytic PTLD } \\
1 \text { Hodgkin PTLD } \\
2 \text { unknown }\end{array}$ & $25 / 31$ \\
\hline Lung & 22 & $11(50 \%)$ & 2001 (1989-2011) & 3.98 & $0.14-13.76$ & $8 / 22(36 \%)$ & $\begin{array}{c}13 \text { DLBCL PTLD } \\
2 \text { MZL PTLD } \\
2 \text { Plasmacytoma-like PTLD } \\
2 \text { Polymorphic PTLD } \\
2 \text { Lymphoplasmocytic PTLD } \\
1 \text { Hodgkin PTLD }\end{array}$ & $17 / 21$ \\
\hline
\end{tabular}

${ }^{a}$ EBV data missing in three cases.

MZL, marginal zone lymphoma; PBL, plasmablastic lymphoma. 
and one case each of marginal-zone PTLD, plasmacytoma-like PTLD, plasmablastic PTLD, and lymphoplasmocytic PTLD (median time-to-PTLD, 7.6 years; range, 3.8-12.0 years).

In comparison with our cases and the data of Opelz et al. (2), the key observation of Jaksch et al. (1) is the low proportion of late (and EBV-negative) PTLD in their transplant cohort. It is therefore possible to speculate that this effect was achieved not only through early administration of CMV immunoglobulin but by optimized immunosuppression throughout follow-up, potentially aided by monitoring of CMV polymerase chain reaction. A reduction of PTLD incidence through viral load monitoring (of EBV viral load) and immunosuppression alteration has previously been demonstrated after heart (5) and pediatric liver (6) transplantation. The test of this hypothesis will be the future incidence of late PTLD in the Vienna cohort.

We would like to note that the differences between our cases and the cohort presented by Jaksch et al. might to some extent reflect selection bias (patients referred to a hematologist for treatment). Furthermore, we did not control for PTLD risk factors such as EBV serostatus at transplantation.

Median overall survival of PTLD after lung transplantation was 1.1 years in the 18 patients reported by Jaksch et al. (1). We observed a median survival of 1.2 years for both our entire cohort of 34 patients and the subgroup of 22 lung transplant recipients. In addition, the four lung transplant recipients treated with sequential therapy (rituximab and $\mathrm{CHOP}$ chemotherapy) in the PTLD-1 trial (3) achieved a similarly poor median overall survival of only 1.0 years compared with a median overall survival of 6.6 years for the entire trial cohort of 70 patients with
PTLD. This reinforces the need for both effective prophylaxis of and improved treatment strategies for PTLD after lung transplantation.

$$
\begin{array}{r}
\text { Heiner Zimmermann } \\
{ }^{1} \\
\text { Sylvain Choquet } \\
{ }^{2} \\
\text { Daan Dierickx } \\
{ }^{3} \\
\text { Martin H. Dreyling }{ }^{4} \\
\text { John Moore } \\
\text { Angelika Valentin } \\
{ }^{6} \\
\text { Jana K. Striefler }{ }^{7} \\
\text { Hanno Riess } \\
{ }^{7} \\
\text { Veronique Leblond }^{2} \\
\text { Ralf Ulrich Trappe }^{1,7}
\end{array}
$$

${ }^{1}$ Department of Internal Medicine II:

Haematology and Oncology

University Medical Center

Schleswig-Holstein, Campus Kiel

Kiel, Germany.

2 Département d'Hématologie

Hopital Pitie-Salpêtriere

Université Pierre et Marie Curie Paris, France.

${ }^{3}$ Department of Haematology University Hospital Gasthuisberg Leuven Leuven, Belgium.

${ }^{4}$ Department of Internal Medicine III University of Munich, Campus Großhadern Munich, Germany.

${ }^{5}$ Haematology Department, St. Vincent's Hospital

Darlinghurst, New South Wales Australia.

${ }^{6}$ Division of Haematology

Medical University of Graz Graz, Austria.

${ }^{7}$ Department of Haematology Charité-Universitätsmedizin Berlin Campus Virchow-Klinikum

Berlin, Germany; for the German PTLD Study Group and the European PTLD Network.

The German and the French PTLD Study Groups were supported by Roche, Amgen, and Chugai to conduct the PTLD-1 trial with an unrestricted grant. The German PTLD D 2006-2012 registry is supported by grants from Amgen,
CLS Behring, Mundipharma GmbH, and Roche Pharma AG.

The authors declare no conflicts of interest.

Address correspondence to: PD Dr. med. Ralf

Ulrich Trappe, Department of Internal Medicine II: Haematology and Oncology, University

Medical Center Schleswig-Holstein, Campus

Kiel, Haus 50, Arnold-Heller Strasse 3, 24105

Kiel, Germany.

E-mail: rtrappe@gwdg.de

Received 2 April 2013.

Accepted 8 May 2013.

Copyright (C) 2013 by Lippincott Williams \& Wilkins ISSN: 0041-1337/13/9603-e18

DOI: 10.1097/TP.0b013e31829b0868

\section{REFERENCES}

1. Jaksch P, Wiedemann D, Kocher A, et al. Effect of cytomegalovirus immunoglobulin on the incidence of lymphoproliferative disease after lung transplantation: single-center experience with 1157 patients. Transplantation 2013; 95: 766.

2. Opelz G, Daniel V, Naujokat C, et al. Effect of cytomegalovirus prophylaxis with immunoglobulin or with antiviral drugs on post-transplant non-Hodgkin lymphoma: a multicentre retrospective analysis. Lancet Oncol 2007; 8: 212.

3. Trappe R, Oertel S, Leblond V, et al. Sequential treatment with rituximab followed by $\mathrm{CHOP}$ chemotherapy in adult B-cell post-transplant lymphoproliferative disorder (PTLD): the prospective international multicentre phase 2 PTLD-1 trial. Lancet Oncol 2012; 13: 196.

4. Trappe RU, Dierickx D, Reinke P, et al. Interim analysis of the largest prospective trial to date in adult CD20-positive post-transplant lymphoproliferative disorder (PTLD): introducing risk-stratified sequential treatment (RSST). ASCO Meet Abstr 2012; 30: 8030.

5. Choquet S, Varnous S, Deback $C$, et al. Adapted management of EBV reactivation after solid organ transplantation: an effective prevention of post transplantation lymphoproliferative disorders (PTLD). Results of the largest prospective study on 251 patients. ASH Annu Meet Abstr 2010; 116: 592.

6. Lee TC, Savoldo B, Rooney CM, et al. Quantitative EBV viral loads and immunosuppression alterations can decrease PTLD incidence in pediatric liver transplant recipients. Am J Transplant 2005; 5: 2222. 